\title{
Browsing the Pacific
}

A popular wide-ranging Pacific Internet report covers the region. However, it is just one element of a larger journalism project that includes advanced, on-the-job training for Pacific Island journalists; and internships for US journalists wanting to learn more about the region.

\section{By AL HULSEN}

THE Pacific Islands Report, providing daily news reports and in-depth commentaries and informational items from and about Pacific Island nations and territories, now is available to computer users worldwide on the Internet. A collaborative service of the Hawai' $i$-based East-West Centre's Pacific Islands Development Programme at the University of Hawai'i's Centre for Pacific Islands Studies, the Pacific Islands Report is available at pidp.hawaii.edu/PIReport'

In addition to news items from island correspondents throughout Melanesia, Micronesia, and Polynesia, and such regional media as the Pacific News Service (PACNEWS), Pasifik Nius (University of the South Pacific journalism programme), Radio Australia, the Samoa News, and the Marshall Islands Journal, the online service also offers detailed reports from Hawai' $i$ and the US mainland that have particular relevance to the Pacific Islands region. The Internet report, however, is just one element of a larger journalism project that includes advanced, on-the-job training for mid-career and junior Pacific Island journalists; internships for US journalists interested in learning more about the Pacific Islands.

The primary goal of the project is to increase global awareness of the Pacific Islands region and its importance to the United States and the world at large. Pacific Islanders' concerns and ideas rarely are heard outside the region, although their warnings and solutions to problems may be of significant worldwide importance. Even in Hawai'i, located almost in the centre of the Pacific Ocean, where local businesses play major regional roles (for example, 
the Bank of Hawaii, Outrigger Hotels and Resorts, and Service) and major regional organisations are based (including the Pacific Islands Conference of Leaders, the United States- Pacific Islands Nations Joint Commercial Commission, the Pacific Basin Development Council, and PREL (Pacific Resources for Education and Learning), coverage of Pacific Islands' news, generally ranges from sparse to ignored. Because of their unfamiliarity, remoteness, small size, and often lack of contemporary communications facilities backwater, hardly considered by the national US and major worldwide media except during times of natural and human disasters. This means such globally significant matters as, for example, the recently concluded French testing of undersea nuclear devices at Moruroa and Fangataufa Atolls, the burning of nerve and mustard gas agents on Johnston Island, Pacific Ocean-wide pollution, the ten year secessionist war in Bougainville, the destruction of coral, indigenous peoples' rights, regional racial strife, mining undersea, wealth, and the like are consistently overlooked by the US East Coast-dominated, generally Euro-centric, mainland print and electronic media (see below).

\section{Background}

The Pacific Islands of Melanesia, Micronesia, and Polynesia-aquatic continentare spread over more than one-third of the earth's surface. The vast Pacific basin, which contains these islands, is encircled by the more familiar Pacific rim. Stretching from the Americas to Asia and Australia, the Pacific Islands region

\section{PACIFIC ISLANDS REPORT}

\section{Thursday, August 27, 1998}

Cook Islands PM Henry Rejects Fiji Critique Of Forum Summit New Cabinet Announced In Marshall Islands Pacific States Still Threatened By Industrial World Bougainville Peace Group Holds First Meeting July CNMI Visitor Arrivals Decline 32 Percent Marine Industry Growing In Tonga PIDP's Halapua Critical Of Pacific Leaders' Economic Plan World War II Veteran's To Re-Live PNG Kokoda Trail Experience

PIR: A partial listing of a news index. 


\section{AL HULSEN}

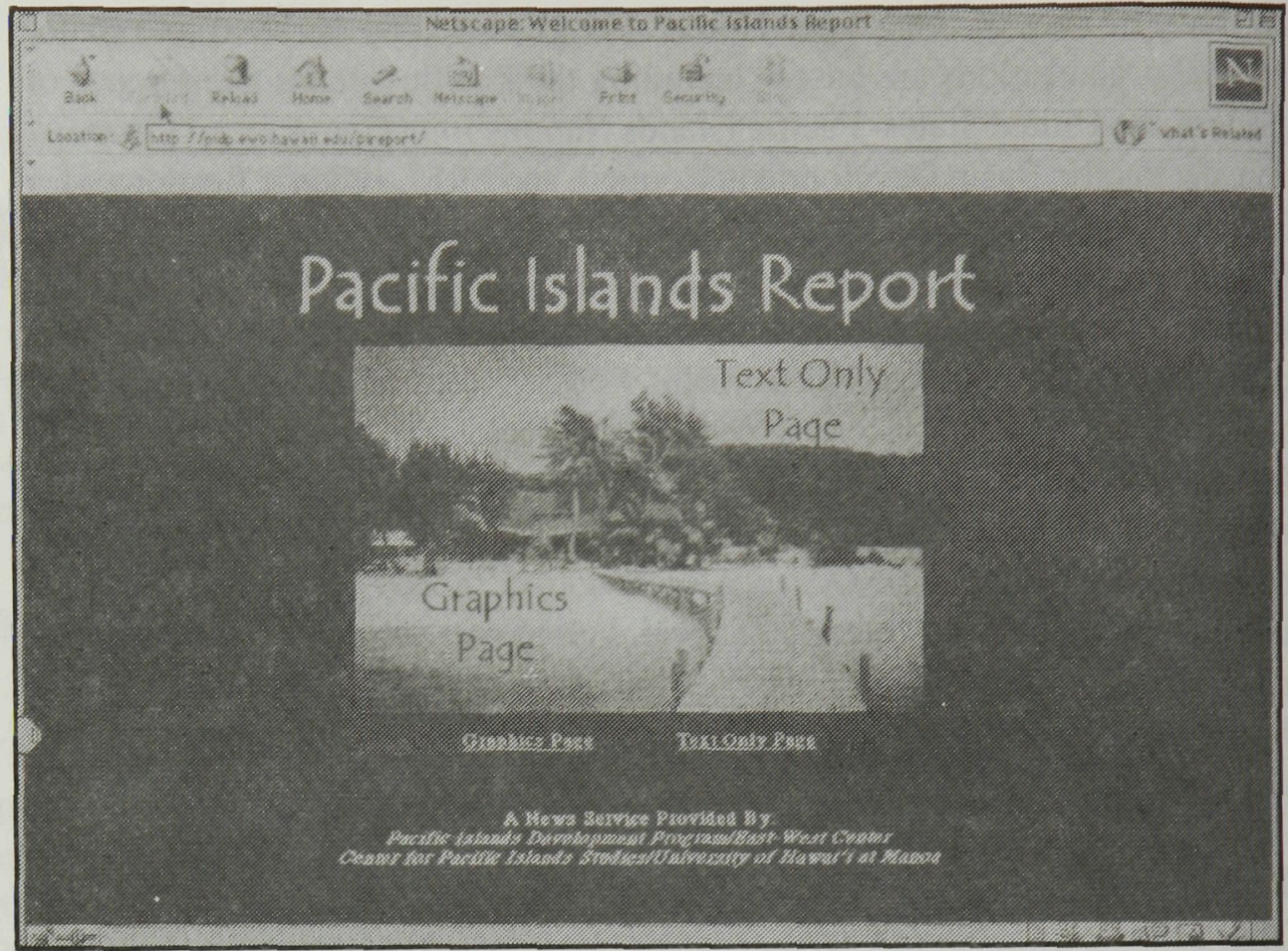

PIR: The front page to the website.

is home to twenty-one independent nations and more than that number of additional island territories administered by Australia, Chile, France, Great Britain, New Zealand, and the United States. US Pacific areas alone, in addition to the fiftieth state of Hawai' i, include American Samoa; Baker, Howland and Jarvis islands; the Commonwealth of the Northern Mariana Islands; Guam; Johnston Atoll; Kure; Midway; Palmyra Island and Kingman Reef; and Wake Island.

Long an area of strategic military importance, with Hawai'i still the headquarters of the Commander in Chief, Pacific Area Command (CINCPAC) and associated US army, navy, marine, and air force components, the Pacific region is also a natural and cultural wonder. The Pacific Islands stimulate the imagination of the world's romantics, as well as its entrepreneurs. Since the voyages of Captain James Cook in the late 1700s, the South Seas have provided images of a sexual nirvana and inspiration to the world "s artists and scientists alike, The region's cultures are almost unbelievably diverse. Pacific Islanders speak more that a thousand distinct languages, more than the rest of the world 


\section{PACIFIC ISLANDS REPORT}

Pacific Island Development Program/Center for Pacific Islands Studies

\section{FREELY ASSOCIATED STATES COMPACTS GENERALLY FAILURE: AMBASSADOR BODDE}

By Al Hulsen

HONOLULU, Hawaii (August 17, 1998 - PIDP/CPIS/Hulsen)-"By most measures," said retired Ambassador Bill Bodde, Jr., speaking about the 15-year US Compacts of Free Association with the Federated Staes of Micronesia, the Marshall Islands and Palau, "they have been a failure".

"There are only two real pluses," he added. For the United States, there has been "unencumbered access to the US Army Missile Range on Kwajalein and denial of access to the region by US adversaries," and the three Freely Associated States, formerly units of the Trust Territory of the Pacific Islands, now have "international status".

The Compact with Palau, providing $\$ 478$ million in assistance over 15 years, became effective only in 1994. But the FSM and Marshalls Compacts, at a cost of some $\$ 3$ billion more, were implemented in 1986 and will expire in 2001. Negotiations to consider renewal of the two older aid agreements are scheduled to begin next year.

In an interview, Bodde said the money spent since 1986 has resulted in "very little economic development" in the newly-independent Micronesian nations, and improvements in the conditions and quality of life "have been marginal in terms of the money received" by the three governments.

PIR: Excerpt from the website.

combined. The Pacific is home to the most exotic and beautiful of nature's physical and living creations. But it is not isolated from the problems that industrialisation continues to create.

Nowhere else has the ecology suffered such disastrous damage through the conduct of war and continued experimental preparations for those conflagrations that may take place in the future. Pacific peoples, as do many others around the remaining two-thirds of the globe, must wrestle first hand with similar problems. They include overpopulation from increasing birth rates and decreasing death rates, drug use, governance conflicts, crime and health crises, natural 


\section{AL HULSEN}

disasters, educational deficiencies, environmental destruction, indigenous rights, AIDS, political corruption, fiscal mis-management, economic crises, the effects of global warming, non-sustainable development, lack of press freedom, and so on.

The Pacific's special contemporary importance to the rest of the world relates to the sea, including the seabed, and the resources for future world-wide sustenance that the Pacific Ocean may offer. Now passing through the Pacific Islands region is some 40 percent of US foreign trade. Yet, this vital and dynamic part of the globe remains virtually unknown, and much too frequently overlooked. The Pacific Islands Report project was developed to address this lack.

\section{Internet}

The Internet version of the Pacific Islands Report was initiated in July 1997. It instantly linked the Pacific to the rest of the world by providing previously unavailable coverage of the day's major regional news stories, as well as indepth reports concerning Pacific Islands issues and ideas. Since the inauguration of the service, Pacific Islanders themselves have provided the majority of the reports. Initially eight new items were offered daily; now twelve to fifteen are provided. Also offered are media releases from the major regional organisations, such as the South Pacific Forum Secretariat, the South Pacific Forum Secretariat, the South pacific Regional Environment Programme (SPREP), the South Pacific Applied Geoscience Commission (SOPAC), and others, as well as officials' speeches, government reports, and major regional documents, including the Noumea Accord pertaining to New Caledonia's future governance, and the cease-fire agreement between the Papua New Guinea government and Bougainville separatists. Each item may be separately download and printed.

The Internet version of the Pacific Islands Report also provides direct links to related web pages, ranging from useful island resources (atlas, currency rates, time, weather) to regional newspapers, magazines, radio or television services, governments, and regional organisations.

During July 1998, full, online coverage of the events celebrating the eightieth birthday of Tongan King Taufa' ahau Tupou IV was offered. Response to the service continues to grow, with correspondence received from across the globe, particularly Asia, Europe, North America, and the Pacific itself. The 
PACIFIC ISLANDS REPORT

report has become a daily news resource for many government agencies worldwide. The regional South Pacific Forum distributes each edition to key staff. Several universities use the Pacific Islands Report as an academic resource, including Tokyo Gakuin University, Stanford University, and the University of Oregon. The report is required reading in many seventh-grade classroom of Hawai'i's public schools, where a semester of Pacific Islands studies is required. Added recently is a "Have Questions about the Pacific Islands" section, which elicits daily queries from around the globe. Answers are provided by the Pacific Islands Development Program, the Centre for Pacific Islands Studies, and other resource personnel.

\section{Newspaper report}

During August 1997, the Pacific Islands Report was expanded to include a newspaper version, which is distributed by email for publication Sunday through Friday in the morning Honolulu Advertiser. Three to five news briefs are included each day in the newspaper's page two Pacific Islands-Asia report.

The Pacific Islands news items summarise selected Internet reports. Distribution of the print report to other publications, particularly on the US mainland and to English-language newspapers in Asia, is planned. The newspaper column includes the Pacific Islands Report Internet address, permitting readers wanting more details to make use of the online report: http:// pidp.ewc.hawaii.edu/PIReport/

\section{Radio report}

Under development is a five-minute radio version of the Pacific Islands Report that will include a three-minute newscast and a two-minute feature item. The host will be a Pacific Islander broadcaster. News items, provided by regional correspondents, will include sound-bite actualities. The radio report, which will originate through KQED, San Francisco, will be uplinked by satellite to public radio stations throughout the United States, including, in the Pacific, Hawai'i, American Samoa, the Commonwealth of the Northern Mariana Islands, and Guam. In addition, it will be transmitted via the PEACESAT facility in Honolulu to most other Pacific Islands entities. The audio Pacific Islands Report also will be transmitted internationally via the Internet, making each edition available by computer throughout the day, at the listener's convenience. 


\section{AL HULSEN}

Journalists

The contributions professional journalists and a free press make to guarantee an informed citizenry

through accurate, fair, objective, and balanced reporting - will help assure the attainment of mature democratic governance and essential national development goals

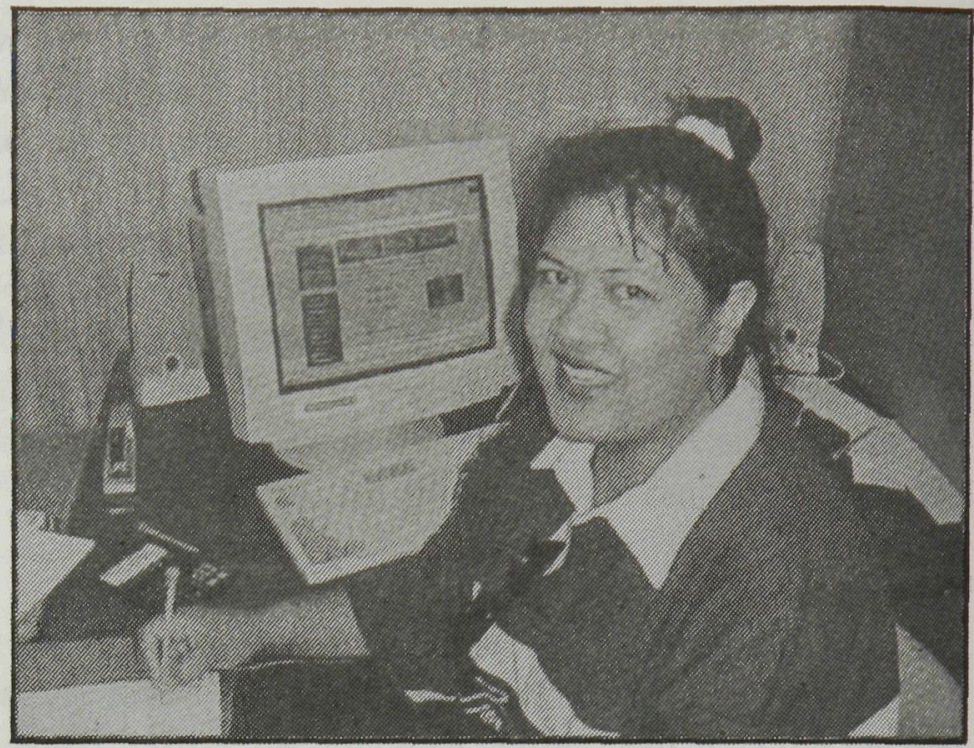

PIR: Masters student Katalina Uili Tohi from Radio Tonga at work.

Photo: ALHULSEN throughout the $\mathrm{Pa}$ -

cific. The project's supervised training internships now involve Pacific Islands journalists directly in the preparation of each day's Pacific Islands Report. The internships permit a sharpening of the journalists' reporting, writing, and editing skills as well as allowing them to experience, firsthand, the meaning and significance of a free press to American democratic governance. Journalists' legal and ethical obligations in preparing and presenting news reports also are considered. Through their participation in the overall Pacific Islands Report activity, it is the project's goal that the interns-the future Pacific Islands media gate-keepers, executives, and policy-makers- will return home better prepared to assure more professional, responsible, and vital media services throughout the widely scattered countries and territories of the region. Since the project's 1997 initiation, one mid-career journalist, from Radio Tonga, and three junior journalists, from Kiribati, Papua New Guinea, and Tonga, all students at the University of Hawai'i, have participated in the project.

\section{Funding}

In addition to financial and in-kind support from the project sponsors, the Pacific Islands Development Program, and the Center for the Pacific Islands Studies, operational funding has been provided by Hawai'i's McInerny Foundation and, 
for interns, the American Association of University Women, Honolulu Chapter. Efforts to obtain additional business, foundation, and government support are under way.

\section{Conclusion}

The long-term benefits of the Pacific Islands Report project are expected to result in greater worldwide awareness and understanding of Pacific Islands achievements and concerns. A global citizenry, better informed about the resources and needs of the region as a whole, will result in international support for more effective and sustainable Pacific Islands development policies and activities.

$\square$ Al Hulsen is the Editor of Pacific Islands Report. This article was originally published in The Contemporary Pacific, Spring 1999, pp 241-247, and has been reprinted with permission.

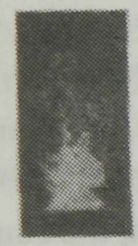

\section{BUSHFIRE MEDIA}

Investigative journalism and documentary research, media critique, progressive publishing in print and on the Web, and feature articles for publication. SPECIALIST IN ASIA-PACIFIC REGION

PO Box 9 Annandale, NSW 2038, Australia bfmedia@mpx.com.au

See Bushfire Media's MEDIA.NET web site at www.mpx.com.au/ bfmedia/ 